\title{
COMPARATIVE STUDY OF INHIBITORY ACTION OF ETHIONINE, 8-AZAGUANINE, 6-MERCAPTOPURINE AND $X$ - OR GAMMA-IRRADIATION ON THE INDUCTION OF THE HEPATIC DRUG-METABOLIZING ENZYMES BY PHENOBARBITAL OR PHENAGLYCODOL
}

\author{
RYUICHI KATO, GIUSEPPE FRONTINO AND PAULO VASSANELLI \\ Institute of Pharmacology, University of Milan, Milan, Italy* \\ Received for publication July 21, 1961
}

Induction of drug-metabolizing enzymes by the administration of drugs was firstly reported by Conney et al. and now it is considered a widely spreaded phenomena in drug metabolism (1-10).

The protein biosynthesis in site of enzyme formation is indispensable process for such induction of enzymes (11).

The inhibitory action of ethionine on induction of several liver enzymes were ascertained in the cases such as tryptophane peroxidase by tryptophane or cortisone, demethylase of dimethylaminoazobenzene by 20 -methylcholanthrene and also glucose-6-phosphatase by hydrocortisone $(1,12,13)$. Also our recent works show the inhibition by ethionine of increased pentobarbital and meprobamate metabolism in vivo induced by phenobarbital, phenaglycodol or Doriden $(4,7)$. On the other hand, it is a well-known fact that in most cases increased biosynthesis of protein is followed by increase in biosynthesis of RNA (14). In recent years, especially, the importance of soluble RNA in biosynthesis of protein by liver microsome was widely recognized $(14,15)$.

It was also reported that as 6-mercaptopurine, 8-azaguanine and X-and gamma-radiation affect on the biosynthesis of nucleic acid, on the regeneration of partially hepatectomized liver, on the formation of antibody and also on induction of some bacterial adaptive enzymes (16-23).

It is a very interesting problem that whether or not de novo biosynthesis of RNA is indispensable for de novo biosynthesis of apoprotein of microsomal drug-metabolizing enzymes.

In the present work the effects of ethionine, 8-azaguanine, 6-mercaptopurine and $\mathrm{X}$ or gamma-irradiation on the induced increase of pentobarbital and meprobamate metabolism in vitro by using liver slice preparation were studied.

\section{MATERIALS AND METHODS}

Male rats of Sprague-Dawley weighing about $70 \mathrm{~g}$ were used in this work.

* Director : Prof. Dr. E. Trabucchi 
Phenobarbital and 6-mercaptopurine were dissolved in distilled water and phenaglycodol and 8-azaguanine were suspended by $0.5 \%$ solution of carboxymethylcellulose and all the solutions were injected intraperitoneally in volume 2 c.c. $/ \mathrm{kg}$ of body weight.

Ethionine was dissolved in $0.9 \% \mathrm{NaCl}$ solution and the solution was injected intraperitoneally in volume 10 c.c./kg of body weight.

All rats received whole-body X-irradiation with Philips Villard super $\mathrm{T}$, in the following conditions; single dosis of $750 \mathrm{r}$, focus distance of $40 \mathrm{~cm}$, filter of $\mathrm{Cu} 0.3+\mathrm{Al} \mathrm{I}$, $161 \mathrm{Kv}, 4 \mathrm{~mA}$., H.V.L. $0.5 \mathrm{~mm}$ Cu.

For whole-body gamma-irradiation "gamma-cell" 220 of Atomic Energy Canada, Ltd. was used. ${ }_{60} \mathrm{C}$ source of 8000 curie. Single dosis of 700 and $1400 \mathrm{r}$.

The determination of pentobarbital was carried out according to the methods of Brodie et al. and the determination of meprobamate to the methods of Hoffman and Ludwig $(24,25)$.

Liver enzyme activities were determined by measuring metabolized pentobarbital and meprobamate by using liver slice preparations after two hours of incubation.

The rats were killed by decapitation and their livers were immediately removed for slicing which were made with a microtom.

After weighing $500 \mathrm{mg}$ of sliced-liver, this is suspended in a Warburg flask containing 6 c.c. of Krebs phoshate buffer pH 7.4 and 0.2 c.c. of $300 \mu$ g sodium pentobarbital or $400 \mu \mathrm{g}$ of meprobamate and incubated at $37^{\circ} \mathrm{C}$ for two hours in a shaking incubater in an atmosphere of oxygen.

At the end of the incubation the reaction mixture was homogenized with a PotterElvehjem-type homogenizer and 2 c.c. of the homogenate were used for the determination.

TABLE 1. Effect of ethionine on the induction of the hepatic drug metabolizing enzymes by phenobarbital and phenaglycodol.

\begin{tabular}{|c|c|c|c|c|c|}
\hline & Pretreatment I & $\begin{array}{l}\text { Interval } \\
\text { between } \\
\text { pretreatment } \\
\text { I \& II }\end{array}$ & Pretreatment II & $\begin{array}{c}\text { Pentobarbital } \\
\text { metabolism } \\
(\mu \mathrm{g} / \mathrm{g} / 2 \mathrm{hrs})\end{array}$ & $\begin{array}{c}\text { Meprobamate } \\
\text { metabolism } \\
(\mu \mathrm{g} / \mathrm{g} / 2 \mathrm{hrs})\end{array}$ \\
\hline 1. & - & & - & $193 \pm 5.9(12)$ & $205 \pm 8.3(12)$ \\
\hline 2. & - & & Phenobarbital & $459 \pm 8.3(10)$ & $508 \pm 12.1(10)$ \\
\hline 3. & - & & Phenaglycodol & $372 \pm 9.1$ & $401 \pm 12.5$ \\
\hline 4. & 一 & & Ethionine $(200 \mathrm{mg} / \mathrm{kg})$ & $183 \pm 5.8(6)$ & $203 \pm 8.3(6)$ \\
\hline 5. & Ethionine $(100 \mathrm{mg} / \mathrm{kg})$ & $30 \mathrm{~min}$ & Phenobarbital & $308 \pm 7.2$ & $303 \pm 14.3$ \\
\hline 6. & Ethionine $(150 \mathrm{mg} / \mathrm{kg})$ & $30 \mathrm{~min}$ & Phenobarbital & $235 \pm 6.3(4)$ & $238 \pm 7.8(4)$ \\
\hline 7. & Ethionine $(200 \mathrm{mg} / \mathrm{kg})$ & $30 \mathrm{~min}$ & Phenobarbital & $209 \pm 5.4(8)$ & $201 \pm 11.2(4)$ \\
\hline 8. & Ethionine & $30 \mathrm{~min}$ & Phenaglycodol & $190 \pm 9.0(6)$ & $213 \pm 14.3(5)$ \\
\hline 9. & Phenobarbital & $6 \mathrm{hrs}$ & Ethionine $(200 \mathrm{mg} / \mathrm{kg})$ & $263 \pm 7.2$ & $281 \pm 9.8$ \\
\hline 10. & Phenobarbital & $12 \mathrm{hrs}$ & Ethionine & $341 \pm 8.1$ & $365 \pm 13.3(6)$ \\
\hline 11. & Phenobarbital & $24 \mathrm{hrs}$ & Ethionine & $393 \pm 5.7$ & $429 \pm 12.4$ \\
\hline 12. & Phenobarbital & $47 \mathrm{hrs}$ & Ethionine & $478 \pm 8.2$ & $513 \pm 10.2$ \\
\hline
\end{tabular}

$70 \mathrm{mg} / \mathrm{kg}$ of phenobarbital and $100 \mathrm{mg} / \mathrm{kg}$ of phenaglycodol were injected intraperitoneally 48 hours before sacrifice for the determination of enzyme activities.

The values are means \pm standard error.

In the brackets showed numbers of animals used.

Significance $=P(0.001(1)-2), 1)-3), 2)-5), 2)-6), 2)-7), 3)-8), 2)-9), 2(-10), 2)-11$ ). N.S. $\quad$ 1) -4$), 2$ ()-12), 1) -8 ). 


\section{RESULTS}

The results are summarily shown in three tables.

Table I shows that $200 \mathrm{mg} / \mathrm{kg}$ of ethionine, which itself does not modify the enzyme activities, antagonizes completely the induction of the enzymes by phenobarbital and phenaglycodol, when it was administered 30 minutes before injection of the inducing drugs, and $100 \mathrm{mg} / \mathrm{kg}$ ethionine showed remarkable effect on the induction of the enzymes.

But ihhibitory action of ethionine was less effective when ethionine was administered after the inducer. In fact, when ethionine was administered 12 hours after the injection of the inducers the inhibitory action of ethionine on the induction was decreased about $50 \%$, and the ethionine administered 47 hours after phenobarbital was completely ineffective. These results suggest ethionine inhibits biosynthesis of apoprotein of the enzymes and it does not affect directly enzyme activities, and it was also demonstrated that the inhibitory action of ethionine was antagonized by the simultaneous injection of the same dosis of methionine.

TABLE 2. Effect of 8-azaguanine and 6-mercaptopurine on the induction of the drug-metabolizing enzymes by phenobarbital and phenaglycodol.

\begin{tabular}{|c|c|c|c|c|}
\hline Pretreatment & $\begin{array}{c}\text { Pentobarbital } \\
\text { metabolism } \\
(\mu \mathrm{g} / \mathrm{g} / 2 \mathrm{hrs})\end{array}$ & variation & $\begin{array}{c}\text { Meprobamate } \\
\text { metabolism } \\
(\mu \mathrm{g} / \mathrm{g} / 2 \mathrm{hrs})\end{array}$ & variation \\
\hline 1. & $197 \pm 5.4(18)$ & & $209_{ \pm} 7.8(16)$ & \\
\hline 2. Phenobarbital & $493 \pm 5.2(8)$ & 1) -2$) \times 2.50$ & $513 \pm 12.4(10)$ & 1) - 2) $\times 2.46$ \\
\hline 3. Phenaglycodol & $380 \pm 6.3(4)$ & 1) -3$) \times 1.93$ & $394 \pm 13.1$ & 1) -3$) \times 1.88$ \\
\hline 4. 8-Azaguanine (a) + Phenobarbital & $392 \pm 10.8(4)$ & $4)-8) \times 2.30$ & $403 \pm 17.5(6)$ & 4) -8$) \times 2.20$ \\
\hline 5. 8-Azaguanine $(b)+$ Phenobarbital & $403 \pm 12.5(6)$ & 5) -9$) \times 2.17$ & $408 \pm 14.3(6)$ & 5) -9$) \times 2.14$ \\
\hline 6. 8-Azaguanine (c) + Phenobarbital & $438 \pm 8.9(4)$ & 6) -10$) \times 2.34$ & $441 \pm 15.1$ & 6) -10$) \times 2.14$ \\
\hline 7. 8-Azaguanine $(d)+$ Phenobarbital & $461 \pm 10.2$ & 7) -11$) \times 2.39$ & $495 \pm 13.2(6)$ & 7) -11$) \times 2.46$ \\
\hline 8. 8-Azaguanine (a) & $171 \pm 9.9(4)$ & & $183 \pm 10.3(4)$ & \\
\hline 9. 8-Azaguanine (b) & $185 \pm 8.3(6)$ & & $191 \pm 7.8(4)$ & \\
\hline 10. 8-Azaguanine (c) & $183 \pm 7.4(4)$ & & $206 \pm 8.5(6)$ & \\
\hline 11. 8-Azaguanine (d) & $193 \pm 6.3(4)$ & & $201 \pm 7.4(3)$ & \\
\hline 12. 8-Azaguanine $(e)+$ Phenobarbital & $342 \pm 11.5(6)$ & 12) -13$) \times 2.05$ & $394 \pm 18.3$ & 12) -13$) \times 2.23$ \\
\hline 13. 8-Azaguanine (e) & $167 \pm 9.4(6)$ & & $177 \pm 10.8(6)$ & \\
\hline 14. 8-Azaguanine (a) + Phenaglycodol & $308 \pm 12.1(4)$ & 4) -14$) \times 1.76$ & $351 \pm 14.0$ & 4) -14$) \times 1.92$ \\
\hline 15. 6-Mercaptopurine (c) + Phenobarbital & $460 \pm 13.1$ & 15) -16$) \times 2.47$ & $498 \pm 12.3$ & 15) -16$) \times 2.34$ \\
\hline 16. 6-Mercaptopurine (c) & $188 \pm 6.3(4)$ & & $213 \pm 6.3(4)$ & \\
\hline 17. 6-Mercaptopurine ( $f$ ) + Phenobarbital & $441 \pm 10.5$ & 17) -18$) \times 2.42$ & $461 \pm 15.8$ & 17) -18$) \times 2.45$ \\
\hline 18. 6-Mercaptopurine ( $f$ ) & $182 \pm 7.2(4)$ & & $188 \pm 7.9(4)$ & \\
\hline
\end{tabular}

$70 \mathrm{mg} / \mathrm{kg}$ of phenobarbital or $100 \mathrm{mg} / \mathrm{kg}$ of phenaglycodol were administered 48 hours before sacrifice.

a) $125 \mathrm{mg} / \mathrm{kg}$ of 8-azaguanine was administered 24 hours before phenobarbital.

b) $125 \mathrm{mg} / \mathrm{kg}$ of 8 -azaguanine was administered 12 hours before phenobarbital administration.

c) $125 \mathrm{mg} / \mathrm{kg}$ of 8 -azaguanine or $100 \mathrm{mg} / \mathrm{kg}$ of 6 -mercaptopurine was administered $30 \mathrm{~min}$ before phenobarbital administration.

d) $125 \mathrm{mg} / \mathrm{kg}$ of 8-azaguanine was administered 12 hours after phenobarbital administration.

e ) $75 \mathrm{mg} / \mathrm{kg}$ of 8-azaguanine was administered four times, $24 \mathrm{hr}, 12 \mathrm{hr}$, and $30 \mathrm{~min}$ before and $12 \mathrm{hr}$ after phenobarbital administration.

f) $50 \mathrm{mg} / \mathrm{kg}$ of 6-mercaptopurine was administered three times : $12 \mathrm{hr}, 30 \mathrm{~min}$ before and $12 \mathrm{hr}$ after phenobarbital administration. 
On the other hands, 8-azaguanine inhibited only partly the induction of the enzymes by phenobarbital or phenaglycodol.

Table 2 shows more than $125 \mathrm{mg} / \mathrm{kg}$ of 8 -azaguanine manifests itself depressor effect on activity of pentobarbital and meprobamate-metabolizing enzymes, however, 8-azaguanine with the non-toxic dosis, in any mode of administration, manifests only a little effect on the induction of microsomal drug-metabolizing enzymes.

Contrary to 8-azaguanine, 6-mercaptopurine did not present any significant effect on the induction of the enzyme, and X- or gamma-irradiation also, in any mode of irradiation, could not affect at all on the induction of the enzymes.

TABLE 3. Effect of $\mathrm{X}$ - or gamma-irradiation on the induction of the drug-metabolizing enzymes by phenobarbital and phenaglycodol.

\begin{tabular}{|c|c|c|c|c|c|}
\hline & Pretreatment I & Pretreatment II & $\begin{array}{l}\text { Interval between } \\
\text { Pretreatment I \& II }\end{array}$ & $\begin{array}{c}\text { Pentobarbital } \\
\text { metabolism } \\
(\mu \mathrm{g} / \mathrm{g} / 2 \mathrm{hrs})\end{array}$ & $\begin{array}{c}\text { Meprobamate } \\
\text { metabolism } \\
(\mu \mathrm{g} / \mathrm{g} / 2 \mathrm{hrs})\end{array}$ \\
\hline $1 .:$ & - & - & & $203 \pm 5.3(12)$ & $212 \pm 6.3(12)$ \\
\hline & Phenobarbital & - & & $499 \pm 8.2(10)$ & $508 \pm 10.5(10)$ \\
\hline 3. & Phenaglycodol & - & & $370 \pm 8.2(4)$ & $389 \pm 10.3(4)$ \\
\hline & $\mathrm{X}$-irradiation (a) & - & & $209_{ \pm} 7.0(4)$ & $208 \pm 7.3(4)$ \\
\hline & Gamma-irradiation (a) & - & . & $215 \pm 8.0(6)$ & $214 \pm 6.8(6)$ \\
\hline 6. & Gamma-irradiation (a) $(0)$ & - & & $182 \pm 9.1(4)$ & $201 \pm 8.3(4)$ \\
\hline 7. & $\mathrm{X}$-irradiation & Phenobarbital & 0 & $480 \pm 10.3(6)$ & $518 \pm 10.9$ \\
\hline & Gamma-irradiation & " & 0 & $503 \pm 11.2(6)$ & $491 \pm 12.1(6)$ \\
\hline & $\mathrm{X}$-irradiation & " & $6 \mathrm{hrs}$ & $483 \pm 8.5(4)$ & $505 \pm 9.5(5)$ \\
\hline & X-irradiation & " & $6 \mathrm{hrs}$ & $472 \pm 11.3(4)$ & $518 \pm 10.3(4)$ \\
\hline & Gamma-irradiation $(\circ)$ & " & $6 \mathrm{hrs}$ & $462 \pm 12.1$ & $469 \pm 14.5(4)$ \\
\hline & Gamma-irradiation & Phenaglycodol & $6 \mathrm{hrs}$ & $387 \pm 10.3$ & $375 \pm 11.5(4)$ \\
\hline & Phenobarbital & $\mathrm{X}$-irradiation & $12 \mathrm{hrs}$ & $492 \pm 13.2(4)$ & $482 \pm 13.1(4)$ \\
\hline & Phenobarbital & $\mathbf{X}$-irradiation & $12 \mathrm{hrs}$ & $465 \pm 12.8(4)$ & $472 \pm 12,8$ \\
\hline
\end{tabular}

$70 \mathrm{mg} / \mathrm{kg}$ of phenobarbital and $100 \mathrm{mg} / \mathrm{kg}$ of phenaglycodol were injected 48 hours before the sacrification.

(a) $\mathrm{X}$-and gamma irradiation was carried out 48 hours before the sacrification.

( o) Gamma-irradiation was carried out with dosis of $1400 \mathrm{r}$.

\section{DISCUSSION}

The mechanisms of the drug-induced increase of hepatic microsomal drug-metabolizing enzymes are not yet clear.

But the facts that as recently reported by Conney et al., hepatic microsomal protein was increased in phenobarbital pretreated young rats (2) and also the fact as demonstrated in this work, that ethionine inhibited the induction of increase of pentobarbital and meprobamate metabolism, indicate that the increased drug-metabolizing enzymes induced by the administration of phenobarbital or phenaglycodol are brought about through the de novo synthesis of enzyme protein.

The facts that low dosis of ethionine administered 30 minutes before the injection of the inducing drugs, inhibited the induction of drug-metabolizing enzymes, and that, on the contrary, 8-azaguanine, 6-mercaptopurine and $\mathrm{X}$ - and gamma-irradiation present only a 
little or no inhibitory actions, suggest the following interpretation.

The induction of increase of the hepatie microsomal drug-metabolibing enzymes might not be indispensable to be accompanied by de novo biosynthesis of microsomal RNA and the usual content of RNA in microsome itself is sufficient for reacting to stimulation of the inducing drugs to carry out the biosynthesis of protein of the apoenzyme.

According to the hypothesis of Creaser there are two types of inducible enzymes, one is 8-azaguanine sensible and the other is 8-azaguanine resistant and the RNA responsible for biosynthesis of 8-azaguanine sensible inducing enzyme is of short active life and that of 8-azaguanine resistant inducing enzyme is of long active life (22). According to the hypothesis of Creaser the RNA responsible for biosynthesis of the inducing hepatic enzymes may be of long active life.

Recently Kvam and Parks reported the inhibition of induced hepatic tryptophane pyrolase (tryptophane peroxidase) and hepatic glucose-6-phosphatase by 8-azaguanine (26). The difference between the results by Kvam and Parks and the results by us may be due to the different length of active life of RNA responsible for biosynthesis of the apoenzyme protein; i.e., the RNA of hepatic tryptophane pyrolase and glucose-6-phosphatase may be of short active life, and that of microsomal drug-metabolizing enzymes may be of long active life.

The difference in the effectiveness between 8-azaguanine and 6-mercaptopurine and the radiation also may be due to the strong side effect of 6 -mercaptopurine and the radiation or to their different actions on RNA biosynthesis.

The results demonstrated in this work, may present some evidences for better understanding of protein biosynthesis in liver microsome.

\section{SUMMARY}

Effects of carcinostatic agents, such as ethionine, 8-azaguanine, 6-mercaptopurine and $\mathrm{X}$ - or gamma-irradiation, on the induction of the hepatic drug-metabolizing enzymes by phenobarbital or phenaglycodol were examined by using young albino rat.

It was observed that ethionine completely inhibited the induction of the enzymes when it was administered 30 minutes before the inducers, but the inhibitory effect of ethionine was diminished when the administration of ethionine was delayed after the injection of the inducers. Ethionine did not directly inhibit the enzyme activity, therefore it was supposed that ethionine inhibits de novo biosynthesis of protein of the apoenzyme.

Contrary to the effect of ethionine, 6-mercaptopurine and X-or gamma-irradiation hardly inhibited or did not inhibit the induction of the enzymes.

The results suggested that the RNA which is responsible for biosynthesis of hepatic microsomal drug metabolizing enzymes may be of long active life.

Acknowledgement. The authors wish to express their sincere gratitude to Prof. Trabucchi for his kind advice and encouragement and also to Prof. Hosoya, Department of Pharmacology, University of Keio, for his kind revision of the manuscript. 


\section{REFERENCES}

1) Conney, A.H., Miller, E.C., Miller, J.A. : Cancer Res. 16, 450 (1956)

2) Conney, A.H., Davidson, G., Gastel, B., Burns, J.J. : J. Pharmacol. 130, 1 (1960)

3) Remmer, H. : Arch. exp. Path. Pharmak. 237, 296 (1959)

4) KATO, R. : Atti Soc. lombarda Sci. med. biol. 14, 777 (1959)

5) KATO, R. : Ibid. 14, 748 (1959)

6) Kato, R. : First Europ. Symp. on Med. Enzymology, Milan p. 363, Karger Pub., Basel (1960)

7) KATO, R. : Medicina experimentalis 3, 95 (1960)

8) KATO, R. : Arzneimittelforsch. 11, 797 (1961)

9) Kato, R. and Ghiesara, E. : Brit. J. Pharmacol. (in press)

10) KAто, R. : Biochem. Pharmacol. (in press)

11) Dixon, N. And WebB, E.C. : Enzymes, Academy Press, New York (1958)

12) LEe, N.D. AND Williams, R.H. : Biochim. biophys. acta 9, 698 (1952)

13) Donald, K.G. And Park, R.E. : Amer. J. Physiol. 198, 21 (1960)

14) Simikin, J.L. : Ann. Rev. Biochem. 28, 145 (1959)

15) Hogland, M.B., Zamecnick, P.C. and Stephenson, M.L. : Biochim. biophys. acta 24, 215 (1957)

16) Davison, J.D. and Freeman, B.B. : Cancer Res. 15, 31 (1955)

17) Garattini, S., Pacilli, N. And Settimini, A. : Chemioterapia 2, 199 (1955)

18) KoHN, H.L. : J. Immund. 66, 525 (1951)

19) Dixon, F.J., Talmage, D.W. and Maurer, P.H. : Ibid. 68, 693 (1952)

20) Schwartz, R., Stagk, J. And Dameshek, W. : Proc. Soc. exp. Biol., N.Y. 99, 164 (1958)

21) Malmgren, R.A., Bennison, B.E. And Makinley, T.W. : J. National Cancer Inst. 12, 807 (1952)

22) Greaser, E.H. : Biochem. J. 64, 539 (1956)

23) Fukumoto, J., Yamamoto, T. and Tsuru, D. : Nature 180, 437 (1957)

24) Brodie, B.B., Burns, J.J., Mark, L.G., Lief, P.A., Bernstein, E. And Papper, E.M. : J. Pharmacol. 109, 26 (1953)

25) Hoffman, A.J. and Ludwig, B.J. : J. Amer. Pharm. Ass. 68, 740 (1959)

26) KVAM, D.G. AND Parks, R.E. : J. biol. Chem. 235, 2893 (1960) 